\title{
TECHNOLOGY FOR REDUCING AIRCRAFT ENGINE POLLUTION
}

by Richard A. Rudey and Erwin E. Kempke, Jr. Lewis Research Center

Cleveland, Ohio 44135

TECHNICAL PAPER to be presented at

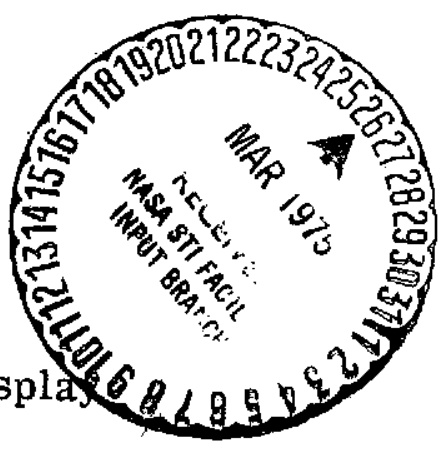
sponsored by the Society of Automotive Engineers Wichita, Kansas, April 9-11, 1975 


\title{
TECHNOLOGY FOR REDUCING AIRCRAFT ENGINE POLLUTION
}

by Richard A. Rudey and Erwin E. Kempke, Jr.

National Aeronautics and Space Administration

Lewis Research Center

Cleveland, Ohio

\begin{abstract}
Programs have been initiated by NASA to develop and demonstrate advanced technology for reducing aircraft gas turbine and piston engine pollutant emissions. These programs encompass engines currently in use for a wide variety of aircraft from widebody-jets to general aviation. Emission goals for these programs are consistent with the established EPA standards. Full-scale engine demonstrations of the most promising pollutant reduction techniques are planned within the next three years. Preliminary tests of advanced technology gas turbine engine combustors indicate that significant reductions in all major pollutant emissions should be attainable in present generation aircraft engines without adverse effects on fuel consumption. Fundamental-type programs are yielding results which inuicate that future generation gas turbine aircraft engines may be able to utilize extremely low pollutant emission combus tion systems.
\end{abstract}




\section{INTRODUCTION}

This paper describes some of the techniques that are being developed and employed to reduce aircraft engine pollutant emissions. The entire spectrum of engines covered by the 1979 EPA Standards will be impacted by the advanced technology development programs now underway. Future engine designs may be affected by fundamental studies also in progress. Results from these advanced technology programs are needed to establish realizable levels for emission pollutant regulations without sacrificing fuel economy.

The Clean Air Act of 1970 charged the EPA with the responsibility to establish acceptable exhaust emission levels of carbon monoxide ( $\mathrm{CO}$ ), total unburned hydrocarbons $(\mathrm{THC})$, oxides of nitrogen $\left(\mathrm{NO}_{\mathrm{x}}\right)$, and smoke for all types of aircraft engines. In response to this charge, the EPA promulgated the standards described in detail in reference [1] and summarized in table I. The standards were issued in 1973 and have provided a significant incentive for the timely development of advanced technology to reduce aircraft engine exhaust emission pollutants. Prior to this time, both the industry and the government were involved in research and development of low emission gas turbine engine combustors. This research provided some input to the proposed levels. Considerable success has already been achieved in reducing the smoke of current jet aircraft engines. The principal technique used was to "lean-out" the combustor primary zone thus eliminating the fuel-rich combustion that produces carbon particle formation [2]. Most of the current JT8D engines, which are used in the 727, 737 and DC-9 aircraft, now have been retrofitted with the low smoke combustors. The newer high pressure ratio gas turbine engines, e.g., JT9D and CF6, employ lean primary zone combustors and are very low in smoke emissions. Because of the progress in smoke reduction, this paper will not describe techniques specifically designed to reduce smoke. However, some of the approaches used to reduce gaseous emissions are also effective for reducing smoke.

* Numbers in brackets designate References at end of paper. 
Aircraft engine exhaust emissions can be broadly divided into five principal categories of constituents as shown in table II (values shown are for a gas turbine engine). The constituents that we are principally concerned with are those resulting from inefficient combustion ( $\mathrm{CO} \& \mathrm{THC}$ ), heating the air in the combustion process $\left(\mathrm{NO}, \mathrm{NO}_{2}\right.$ or more commonly called $\mathrm{NO}_{x}$ ) and impurities contained in the fuel $\left(\mathrm{SO}_{2}, \mathrm{SO}_{3}\right.$ or $\left.\mathrm{SO}_{\mathrm{x}}\right)$. The $\mathrm{SO}_{\mathrm{x}}$ emissions can be reduced to negligible quantities by reducing the sulphur content in the fuel. The CO, THC, and $\mathrm{NO}_{\mathrm{x}}$ emissions that are caused by inefficient combustion and heating of the air can be controlled by engine and/or combustor design.

Some of the advanced technology being developed to reduce gaseous emissions for current and future gas turbine and piston aircraft engines is described and discussed in this paper. Although considerable work is being supported by other government agencies (DOD, FAA, \& EPA), the main source of information used in the preparation of this paper is from the programs being conducted at or under the sponsorship of the NASA Lewis Research Center. The paper is divided into two main categories: gas turbine aircraft engines and piston aircraft engines. The effort on gas turbine aircraft engines will be more thoroughly described since the majority of the on-going low emission advanced technology development has been for these engines.

\section{GAS TURBINE ENGINE TECHNOLOGY}

The level of gaseous emission pollutants varies with engine operating conditions, for most conventional combustors, as illustrated in figure 1 . The emission index ( $\mathrm{g}$ pollutant/kg of fuel burned) levels of $\mathrm{CO}$ and THC are highest at the off-design operating conditions, such as idle, where combustion efficiency is lower than at the design operating condition (near takeoff). Conversely, the $\mathrm{NO}_{\mathrm{x}}$ (normal practice is to express $\mathrm{NO}_{\mathrm{x}}$ levels in terms of $\mathrm{NO}_{2}$ ) is the highest at the takeoff condition primarily because the combustion gas temperatures are their highest. The rate of $\mathrm{NO}_{\mathrm{x}}$ production is known to be a function of the gas temperature and the 
residence time that free nitrogen and oxygen are exposed to the high temperature [3]. The relationship of engine operating condition to the combustion process is shown in figure 2. This figure relates the causes, effects, results, and cures for the pollutant emissions at the two extreme operating conditions, i.e., low power idle and high power takeoff. During low power idle operation, combustor inlet temperature, $\mathrm{T}_{\text {in }}$, and pressure, $\mathrm{P}_{\text {in }}$, and fuel-air ratio, $\mathrm{F} / \mathrm{A}$, are low causing the effects which contribute to combustion inefficiency and thus the production of $\mathrm{CO}$ and THC. At high power takeoff, combustor inlet temperature and pressure, and fuel-air ratio are all high which results in high combustion flame temperature, plus the other effects shown, all of which contribute to the production of $\mathrm{NO}_{\mathrm{x}}$. Since aircraft gas turbine engines must operate effectively at both extremes (idle and takeoff) and many conditions between them, low emission combustors that are compatible to all operating conditions must be developed. If we observe the list of "cures" shown in figure 2, we can recognize that a dilemma exists at the two operating extremes. Those "cures" which can reduce CO and THC are directly the opposite of those required to reduce $\mathrm{NO}_{\mathrm{x}}$ with one exception; improved fuel distribution. Our challenge then is to develop advanced combustor technology that can take advantage of the needed "cures" at a particular engine operating condition without adversely effecting the pollutant production at the other operating conditions.

POLLUTION CONTROL TECHNIQUES - Some of the techniques which can be used to reduce low power emissions are illustrated schematically in figure 3. The "tulip" spray pattern shown is indicative of poor fuel atomization resulting from low fuel flow and pressure in pressureatomizing type fuel nozzles. All three techniques shown can improve fuel atomization. The air-assist and air-blast fuel nozzles use high pressure and high velocity air to aid in atomizing the fuel. 'The fuel scheduling approach reduces the number of fuel nozzles that are supplied with fuel. Thus, for a given $\mathrm{F} / \mathrm{A}$ the fuel flow through each nozzle is increased and atomization is improved. In addition, fuel scheduling increases local fuel-air ratio and can improve fuel distribution. Applying any or all of these techniques improves combustion efficiency. 
Some of the techniques which can be used to reduce high power emissions are illustrated schematically in figure 4 . In a conventional combustor, near stoichiometric fuel-air ratios (the fuel-air ratio needed to completely burn all of the fuel) are present in the flame zone thus producing high gas temperatures which promote the formation of $\mathrm{NO}_{x}[4]$. Also, the flame zone is rather large resulting in long residence times in the hot gas. Both the leaner mixture and premixing techniques are aimed at controlling the gas temperature in the flame zone to reduce the $\mathrm{NO}_{\mathrm{x}}$ formation by allowing combustion at fuel-air ratios much less than stoichiometric (lean combustion). The swirl-can technique (many small combustion modules arranged in an annular array) provides some capability for lean combustion and also reduces the residence time because the flame zone is broken down into many small zones instead of one large one.

In addition to the above control techniques, which are accomplished by combustor design, other approaches such as water injection for $\mathrm{NO}_{\mathbf{x}}$ reduction and increasing compressor bleed for improving idle efficiency are also effective for reducing pollutant emissions. Manipulation of combustor operating variables such as reference velocity, $v_{R E F}$, is another effective technique [5].

EVALUATION OF CONTROL TECHNIQUES - The effectiveness of the various control techniques have been and are continuing to be evaluated by NASA through in-house and contract research programs. Fundamental as well as full scale experimental combustor studies are being utilized.

Fundamental Studies - One very simplified approach to achieving substantial reductions in $\mathrm{CO}$ and THC emissions at idle is to use the air-assist type fuel nozzle to improve fuel atomization. One method of using this approach is shown schematically in figure 5. High pressure (higher than combustor inlet pressure) air is supplied through a valve and tee arrangement into the secondary fuel supply line of a duplex fuel nozzle. This is possible at idle since fuel is supplied only to the nozzle primary fuel passage. For high power operation, the compressed air 
would be shut off and fuel supplied to both the primary and secondary fuel passages in the nozzle. To use this approach in an engine would require some sort of external compressor or supercharger as shown on the schematic. The resultant effect of supplying high pressure air to the nozzle of a can-type combustor is shown in figure 6 , where the exhaust emissions of $\mathrm{CO}, \mathrm{THC}$, and $\mathrm{NO}_{\mathrm{X}}$ are plotted as a function of the air-assist differential pressure. THC emissions were reduced by about a factor of eight and $\mathrm{CO}$ by a factor of three. A negligible increase in $\mathrm{NO}_{\mathrm{x}}$ production was observed. Similar studies conducted using the air-blast and fuel scheduling approaches also produced significant reductions in $\mathrm{CO}$ and THC. [6] and [7].

The effect of prevaporizing and premixing fuel and air on the formation of $\mathrm{NO}_{\mathbf{x}}$ is under study at Lewis using a flame tube rig shown schematically in figure 7. Gaseous Propane or atomïzed Jet-A is injected upstream of a perforated flame holder with sufficient distance to provide a completely prevaporized/premixed fuel-air mixture to the primary zone (flame zone) test section. Exhaust gas samples can be extracted at varying distances downstream of the flame holder to insure that combustion is completed at the sample measurement position. Some of the results obtained to date are presented in figure 8 where the emission index of $\mathrm{NO}_{\mathrm{x}}$ is plotted for two inlet temperatures as a function of equivalence ratio, $\phi$ (ratio of local fuel-air ratio to the stoichiometric fuel-air ratio). Extremely low values of $\mathrm{NO}_{\mathrm{x}}(<1 \mathrm{~g} / \mathrm{kg})$ were obtained at the very lean equivalence ratios $(<0.6-0.5)$ for the two inlet temperatures tested. The good agreement with well-stirred reactor (WSR) model predictions indicates that good premixing was obtained. The lowest values were obtained at the edge of the combustion flammability limits and any slight perturbation in flow caused combustion blowout. Because of this stability sensitivity, these results are considered to be near the fundamental lower limit of $\mathrm{NO}_{\mathrm{x}}$ emissions for the type of experimental hardware used in this investigation. It is important to note that the operating conditions for this experiment were very carefully controlled and do not necessarily duplicate conditions in an actual engine except for the levels of inlet pressure and 
temperature which simulate a typical supersonic cruise condition. More details of this experiment are given in [8].

Fundamental test results such as these, indicate that the premix approach is a prime candidate for achieving low values of $\mathrm{NO}_{\mathbf{x}}$ in gas turbine combustion systems. A similar experiment with similar results, [9] is being conducted under contract with Advanced Technology Laboratories.

Another evaluation of the premix technique is being conducted under contract to the Solar Division of International Harvestor using "quasi-combustor" type tubular test hardware, figure 9. Concepts A and $B$ represent two different approaches to achieve very lean combustion using premixed fuel-air. Concept $A$ uses jets of premixed fuel-air to create a large recirculation of hot gases into the flame zone which aids in maintaining combustion stability at very low equivalence ratios. Concept $B$ uses a rotating flow field to create a similar effect. Concept $\mathrm{C}$ provides premixed fuel-air to a catalytic bed in which the $\mathrm{H}, \mathrm{C}, \mathrm{O}$ reactions occur. In the catalytic bed, the gas temperature can be controlled at levels below which $\mathrm{NO}_{\mathrm{x}}$ formation is negligible $(<1800 \mathrm{~K})$. Testing of these concepts is expected to be completed in mid 1975.

Experimental Combustors - The majority of effort on the evaluation of low pollutant emission combustors conducted in-house by NASA has been with the swirl-can-modular combustor shown in figure 10. Figure $10(a)$ is a photograph of a full-annular array of 120 swirl can modules arranged in three radial rows. A cross-sectional view of this combustor is shown in figure $10(\mathrm{~b})$ and the components of the swirl can module are illustrated in figure 10(c). Each module is composed of a carburetor cup, swirler, and flame stabilizer. Fuel is injected into the carburetor cup where it premixes with air flowing through the cup and then passes through a swirler into the wake created by the flame stabilizer which acts as a quasi-bluff body in the air flowing around the module. The swirling fuel-air mixture provides for a small stable flame zone in the stabilizer wake. 
The combination of a small flame zone and premixed fuel-air provides for low residence times and some degree of gas temperature control in the flame zone. Typical $\mathrm{NO}_{\mathrm{x}}$ emission results obtained with this type of combustor, compared to conventional combustors, is shown in figure 11. Thirty to fifty percent reductions in $\mathrm{NO}_{\mathrm{x}}$ emissions are indicated at operating conditions representative of narrow and wide body commercial jet aircraft engines. This combustor can also use the fuel scheduling (fueling only one row of modules) technique for reducing $\mathrm{CO}$ and THC emissions.

Other types of NASA experimental combustors have also been evaluated in terms of their potential for reducing pollutant emissions. A double-annular combustor [10] has been used to further study the effects of fuel scheduling for reducing $\mathrm{CO}$ and THC at idle. A NASA in-house program to study small (5-10 lbs/sec) reverse and axial flow combustor performance and emission characteristics will be initiated in 1975.

ASSESSMENT OF CONTROL TECHNIQUES - The degree of difficulty involved in applying the various control techniques discussed to actual engine acceptable hardware must be assessed in relation to the potential for reducing pollutant emissions. Only through such an assessment can we arrive at sensible trade-offs between pollutant emission goals and the time and cost to implement control techniques. In a qualitative way, this assessment is given in table III. As one might expect, those techniques that have the best potential for reducing all pollutant emissions also require major modifications in terms of current combustor technology and present the most difficult development risk. Risk is defined as the ability to convert a demonstrated experimental technique into a workable engine combustor. Good reductions in $\mathrm{CO}$ and THC emissions may be achievable with minor or moderate modifications and with a low development risk. However, any appreciable reduction in $\mathrm{NO}_{\mathbf{x}}$ will require major modification and moderate to high development risk. It should be understood that several of these techniques can be combined in a staged type combustor and that the optimum control of emission may require combinations and variable geometry. 
From the preceding discussion it is obvious that quantitative information is needed if we are to be successful in making satisfactory and sensible trade-offs. The obtainment of quantitative information has been initiated by NASA through a series of advanced technology combustor development programs aimed at demonstrating emission performance in a wide variety of existing engines. The scope and goals of these programs will be discussed in the next section of this paper.

APPLICATION OF CONTROL TECHNIQUES - The application of pollutant emission control techniques is being implemented in two large NASA/Industry programs.

Experimental Clean Combustor Program - The first of these programs, the NASA Experimental Clean Combustor Program (ECCP), was initiated in December of 1972. The program objective is to develop and demonstrate, in full-scale engine tests, advanced technology combustors that are capable of reducing pollutant emissions in the large high by-pass ratio engines (EPA Class T2, thrust over 8000 lbs) that power the wide body jets. The emission level goals are consistent with the published EPA standards. The two contractors that were selected, and are currently under contract, are Pratt \& Whitney Aircraft (JT9D engine) and the General Electric Company (CF6 engine). The program is a three-phased effort scheduled to culminate in engine demonstration tests in 1976. Phase I of the program (screening of a multitude of low emission concepts) has been completed and the two most promising combustor concepts have been chosen for phase II (refinement for engine adapation) which is now underway. A complete description of this program is given in reference 11 .

The two advanced technology CF6 engine combustor configurations that will be evaluated in Phase II are shown along with the standard CF650 combustor in figure 12(a). Both designs utilize the concept of fuel scheduling for reducing idle pollutant emissions. The pilot stages of 
both the radial/axial staged and the double annular are optimized for high efficiency (low $\mathrm{CO} \& \mathrm{THC}$ emissions) at engine idle fuel-air ratios. The main stages are optimized for lean combustion (low $\mathrm{NO}_{\mathrm{X}}$ ) at full-power fuel-air ratios. Various combinations of fuel scheduling can be used for off-design operation such as approach and climb out power settings. The radial/axial staged configuration utilizes a premixed fuel-air approach in the main stage whereas the double annular configuration uses an air-blast ty pe nozzle to obtain lean combustion in the main stage. These two configurations employ four of the previous discussed control techniques: (1) fuel scheduling, (2) air blast fuel nozzles, (3) lean mixture combustion, and (4) premixing.

The two advanced technology JT9D engine combustor configurations that will be evaluated in Phase II are shown along with the standard JT9D combustor in figure 12(b). As with the CF6 configurations both designs use fuel scheduling as the principal approach to controlling idle pollutant emissions. Optimization of the individual stages at idle and full power conditions is used for overall emission control. The hybrid configuration utilizes a parallel (radial) fuel staging approach with a premix technique in the pilot stage and a variation of the swirl can concept in the main stage. This configuration is an attempt to mate the lowest $\mathrm{CO} \& \mathrm{THC}$ emission design (premix pilot stage) and the lowest $\mathrm{NO}_{\mathrm{x}}$ emission design (swirl-can-module stage) that was tested in Phase I. The vorbix configuration utilizes a seriestype (axial) fuel staging approach with standard type pressure atomizing fuel nozzles in the pilot and main stages. The main stage has high intensity swirlers immediately downstream of the fuel injection point to promote very intense, rapid mixing of the fuel and air in the flame zone. The combination of the intense mixing and hot gases exiting from the pilot stage allow lean operation in the main stage and also reduce residence time due to quick quenching of the hot gases. These configurations also employ four of the control techniques: (1) fuel scheduling, (2) lean mixture combustion, (3) premixing, and (4) modular combustion. Results from the Phase I tests will be discussed in a later section. 
Pollution Reduction Technology Program - The second major program that is being implemented to apply low pollutant emission control techniques is the Pollution Reduction Technology Program (PRTP). The PRTP was initiated in mid 1974 as an effort to develop advanced technology combustors to reduce pollutant emissions of the three classes of engines included in the 1979 EPA standards that are not covered by the ECCP. The engines selected for the PRTP are the Pratt \& Whitney JT8D (EPA class T4), the GarrettAiResearch TFE731 (EPA class T1, thrust less than 8000 pounds), and the Detroit-Diesel Allison 501-D22 (EPA class P2, turboprop). All three engine combustor evaluations will be conducted in a multiphase approach similar to the ECCP with engine demonstrations scheduled in 1976 and 1977. Combustor concept design and fabrication and some preliminary testing is in progress with the bulk of the Phase I screening tests scheduled to be completed near mid 1975. Program goals are: consistent with published 1979 EPA standards.

The combustor configurations selected for the Phase I screening tests are shown in figure 13(a) through (c) for the JT8D, TFE731, and 501-D22, respectively. Two to three advanced technology configurations of each engine combustor were selected for evaluation based on the degree of emission reduction potential and development risk involved. In all cases the selected configurations representing the least development risk ( $A$ or $B$ ) have the least likelihood of achieving all of the pollutant emission goals. The $\mathrm{C}$ or $\mathrm{D}$ configurations represent the highest development risk but provide the best chance of achieving or exceeding the pollutant emission reduction goals.

The JT8D configurations will utilize air-assist fuel nozzles, air blast fuel nozzles, fuel scheduling, lean mixture combustion, and premixing control techniques. The TFE731 configurations will use all of the above techniques and will also document the effects of increased compressor discharge bleed and water injection. The 501-D22 configurations will also use the same techniques described under the JT8D engine. Although all the engine programs use the same type of control techniques, the applications vary. For example, the TFE731 configuration uses 
parallel or radial fuel scheduling (configuration C) whereas the 501-D22 uses series or axial fuel scheduling (configuration D). Other differences of note are that the JT8D and 501-D22 are can-annular combustors whereas the TFE731 is a full annular design and that the TFE731 is a reverse flow design versus the axial flow types of the JT8D, 501-D22 and the JT9D and CF 6 of the ECCP.

The essential point is that although the pollutant control techniques are similar for all combustors, the methods for applying these techniques to actual engines must be varied as the individual engine configuration dictates. The degree of success will be not only dependent upon the control techniques used but will to a great degree depend upon the ability and ingenuity of the engineer to adapt these techniques to his engines' specific characteristics.

PROGRESS TO DATE - The results of the ECCP (JT9D \& CF6 engine combustor configurations) Phase I tests are illustrated in bar chart form on figure 14. This figure compares current engine emission index values of $\mathrm{CO}, \mathrm{THC}$, and $\mathrm{NO}_{\mathrm{x}}$ with the advanced technology combustor rig test results and the estimated engine levels needed at the idle and take off condition to achieve the EPA 1979 standards. Emission levels below (the dashed lines represent a range of results from various configurations) the required EPA CO and THC values have been obtained with the advanced designs. None of the configurations tested so far have been able to achieve the required EPA NO ${ }_{x}$ level with an acceptable combustion efficiency ( $>99$ percent). Very low values of $\mathrm{NO}_{\mathrm{x}}$ are obtainable at reduced efficiencies but this is an unacceptable alternative because of fuel consumption considerations. All of the results shown were obtained in combustor rig tests and will not be verified in engines until Phase III is conducted.

Substantial reductions in $\mathrm{NO}_{\mathrm{x}}$ emissions, compared to current combustors, have also been demonstrated in fundamental laboratory tests under carefully controlled conditions simulating high altitude cruise engines. The results of some of these studies are summarized and compared with $\mathrm{NO}_{\mathrm{x}}$ emissions from current engines (Concorde type) 
and advanced technology (ECCP type configurations) combustors in figure 15. The results are extremely encouraging and indicate "potential" reductions of tenfold or greater at simulated supersonic cruise conditions. It is likely, however, that several more years of laboratory studies will be needed before we can proceed to the combustor concept development and demonstration stage that will be necessary to make the final judgment of what value is realistically achievable. The estimated $\mathrm{NO}_{\mathrm{x}}$ emission index of 6 to 8 for the advanced technology combustors (ECCP type configurations) at subsonic cruise conditions represents about a two- to three-fold reduction from current JT9D and CF 6 cruise values. To obtain further reductions will likely require more sophisticated (staged and prevaporized/premixed fuel-air techniques) concepts than have currently been tested in full-scale combustors. The development of variable geometry combustors will likely be required.

\section{PISTON ENGINE TECHNOLOGY}

Current aircraft piston engines are generally operated at "fuel rich" mixture settings for other than cruise condition, and as such, discharge exhaust emissions that are high in THC and CO. Oxides of nitrogen are within the EPA limits. Table II shows the reductions in THC and CO emissions that must be accomplished without increasing $\mathrm{NO}_{\mathrm{x}}$. Unique differences between the automotive and aircraft piston engine requirements and design may preclude the application of the many automotive pollution reduction methods to general aviation aircraft engines. Aircraft piston engines are generally. air-cooled rather than liquid-cooled and are designed to operate under minimal margins of speed and power and with more stringent requirements for safety, while at the same time sustaining a low drag geometry and minimum weight. These factors indicate that technological advancements specific to aircraft engines may be needed to achieve compliance with the EPA Emission Standards. 
EVALUATION OF CONTROL TECHNIQUES - The scope of the NASA piston engine technology program includes measuring baseline emissions, determining the effects of $\mathrm{F} / \mathrm{A}$ ratio and ignition timing on emissions and performance, analyzing and investigating alternative control techniques, testing prototype engines, and assessing alternative engines for future generation light aircraft. The program has three elements.

FAA/NASA Control Effort - The first program element is a joint FAA/NASA contractual effort initiated June 1974 with AVCO Lycoming and Teledyne Continental. Phase I will provide baseline characterization of the emissions from 10 representative aircraft engines and determine the effects of variable $F / A$ ratios and timing modifications on emission level and engine operation (cooling, misfire, roughness, etc). Phase II will consist of the analysis and design of minor engine modifications which offer promise toward achieving the emission levels. Limited testing of the proposed modifications will be conducted in Phase III.

NASA Contract Effort - The second program element is a NASA contractual effort that would screen and assess more significant modifications and include demonstration tests of those concepts showing the most promise. A partial list of candidate emission reduction techniques is shown in table IV.

The criteria to be used in the evaluation of these techniques will include: technical feasibility to reduce emissions and specific fuel consumption; status of technology; cost; weight; safety; operational characteristics; noise; ease of manufacture; ease of integration on new engines and adaptability to the various existing engine/aircraft configurations; maintenance and reliability; cooling; engine/aircraft performance; and availability of fuel additives.

Lewis In-house Research Effort - The third program element is a Lewis Research Center in-house research effort consisting of studies and analyses, aircraft engine experiments, and alternative engine experiments. 
Detail studies and analyses will be made of aircraft piston and alternative engines. The studies and analyses will include feasibility assessments, system and cycle calculations in order to determine the predicted benefits, operational problems, and technology requirements imposed by various pollutant emissions reduction techniques. An assessment will also be made of rotary combustion engines, Stirling cycle engines, and diesel engines for potential application to future general aviation aircraft.

An experimental investigation of two aircraft engines (Lycoming 0-320-D and Continental TS10-360-C) to obtain baseline performance, a correlation of humidity effects on emission levels and performance, and to evaluate the effectiveness of various emission reduction techniques is currently being conducted. Three emission control techniques being investigated are thermal reactors, hydrogen injection, and water-alcohol injection.

Operation of internal combustion engines in the "ultra-lean" $\mathrm{F} / \mathrm{A}$ region can produce considerable reduction in exhaust pollution with a potential increase in fuel economy. However, good combustion of lean mixtures using gasoline has been difficult to achieve in practice. A possible solution is to inject relatively small amounts of hydrogen gas into a lean gasoline and air mixture in order to extend the flammability limit. Problems with this technique lie in the development of a practical hydrogen generator system, an increase in complexity due to a hydrogen injection system, and a requirement for larger engines or supercharging to restore the engine pawer lost due to lean operation.

An experimental investigation to assess basic feasibility of hydrogen generation and injection is being performed using an automotive test engine prior to its evaluation on aircraft piston engines. A methanol fuel hydrogen generator composed of a vaporizer, catalyst bed, intercooler and controls, figure 16 , has been installed and is being tested on the engine. The system generates relatively small quantities of hydrogen by a steam reformation process from a methyl alcohol/water mixture passing over a catalyst heated from the engine exhaust. 
Thermal reactors appear to be a good technique for reducing the carbon monoxides and unburned hydrocarbons. A better assessment of the practical problems of engine integration, safety, turbocharged versus naturally aspirated, mechanical integrity, and system complexity is being performed in concert with the aircraft manufacturers and the FAA. Should the assessment indicate that this could be a viable approach, a thermal reactor would be designed and its performance experimentally evaluated.

Significant reductions in aircraft piston engine $\mathrm{CO}$ and $\mathrm{THC}$ emissions can be achieved with improved fuel management systems consisting of controlled leaning out of the engine air-fuel mixture. The air-fuel mixture at high power (take-off and climb) of current high performance engines is excessively rich to prevent overheating and detonation. However, with the injection of the water-alcohol fluid, the mixture may be leaned out because the vaporization of the water-alcohol mixture can provide the cooling formerly supplied by the excess fuel.

The above evaluations, along with the Wankel rotary engine investigation, will provide a large data base for the assessment of potential engine emission controls for future applications to piston engine powered aircraft.

\section{CONCLUDING REMARKS}

The major techniques required to control the emission levels of $\mathrm{CO}, \mathrm{THC}, \mathrm{NO}_{\mathrm{x}}$, and smoke for gas turbine aircraft engines are well known and documented. Research efforts to define the ultimate capability of these techniques to reduce pollutant emission levels will continue to be conducted in NASA in-house facilities and under NASA sponsorship with industry and universities. The successful application of these techniques to operational engine combustor hardware will depend upon the ability and ingenuity of the engineer to adapt the techniques to the particular characteristics of his engine. The NASA/ Industry Experimental Clean Combustor and Pollution Reduction Technology Programs will provide quantitative information needed for 
evaluating the trade-offs between development risk and emission reduction potential for a wide variety of engine and combustor types. The ability to successfully achieve the required EPA emission standards (in terms of levels and implementation time), for selected engines, will be resolved by engine demonstration tests during 1976 and 1977 .

The potential impact of gas turbine engine high altitude cruise emissions on our environment is currently under heavy debate. Considerable information and data are being obtained but more is needed. Air quality measurements over long periods of time are required and programs to obtain these measurements are being implemented. Several more years of laboratory studies to evaluate attractive approaches to reduce $\mathrm{NO}_{\mathrm{x}}$ formation to minimum values in combustion systems are still needed prior to undertaking combustor concept development and demonstration. Combustors must be developed and demonstrated in actual engines at simulated high altitude cruise conditions before we can realistically project achievable levels for future high altitude aircraft engine $\mathrm{NO}_{\mathrm{X}}$ emissions .

Safety, weight, and performance considerations may prohibit the application of most automotive pollution reduction methods to general aviation piston engines. Therefore, technological advancements specific to aircraft engines will likely be required to achieve compliance with the EPA Emission Standards. Research efforts to establish and demonstrate the necessary technology to reduce the exhaust emissions will be conducted in NASA in-house facilities and under NASA sponsor ship with industry.

Reductions in aircraft engine pollutant emissions, both gas turbine and piston, must be accomplished without adversely affecting engine fuel consumption and overall performance. Experimental programs conducted to date indicate that acceptable performance and fuel consumption can be maintained if the reduced emission technology is properly implemented. 


\section{REFERENCES}

1. "Control of Air Pollution for Aircraft Engines-Emission Standards and Test Procedures for Aircraft." Federal Register, Vol. 38, July 17, 1973, pp. 19088-19103.

2. J. Grobman and L. C. Papathakos, "Smoke Evaluation of a Modified J-57 Combustor." National Aeronautics and Space Administration TMX-2236, Mar. 1971.

3. I. Glassman, "Combustion Science and Technology." Princeton University, 1970.

4. D. Thompson, "NO $\mathrm{x}_{\mathrm{x}}$ Formation in Combustion." Combustion and Flame, Vol. 19, Aug. 1972, pp. 69-79.

5. J. Grobman, "Effect of Operating Variables on Pollutant Emissions from Aircraft Turbine Engine Combustors." National Aeronautics and Space Administration TMX-67887, Sept. 1971.

6. R. D. Ingebo and C. T. Norgren, "High-Pressure Combustor Exhaust Emissions with Improved Air-Atomizing and Conventional Pressure Atomizing Fuel Nozzles." National Aeronautics and Space Administration TN-D-7154, Feb. 1973.

7. T. R. Clements, "Effects of Fuel Zoning and Fuel Nozzle Design on Pollution Emissions at Ground Idle Conditions for a Double-Annular Ram-Induction Combustor." Pratt and Whitney Aircraft FR-5295, Feb. 1973; also National Aeronautics and Space Administration CR-121094, Feb. 1937.

8. D. Anderson, "Effects of Equivalence Ratio and Dwell Time on Emissions from an Experimental Premixing Prevaporizing Burner." Paper to be presented at 20th Annual International Gas Turbine Conf., Houston, Tex., Mar. 2-6, 1975.

9. G. Roffe and A. Ferri, "Prevaporization and Premixing to Obtain Low Oxides of Nitrogen in Gas Turbine Combustors." National Aeronautics and Space Administration CR-2495, 1975. 
10. D. F, Schultz, "Modifications That Improve Performance of a Double Annular Combustor at Simulated Engine Idle Conditions." National Aeronautics and Space Administration TMX-3127, Dec. 1974.

11. R. W. Niedzwiecki and R. E. Jones, "The Experimental Clean Combustor Program - Description and Status. " Paper presented at the Air Transport Meeting, Dallas, Tex., Apr. 30-May 2, 1974. 
Figure Captions

1. Typical aircraft gas turbine engine exhaust emission characteristics.

2. Aircraft gas turbine combustor pollution considerations.

3. Emission reduction techniques at idle.

4. Emission reduction techniques at full power.

5. Schematic of an air-assist fuel injection configuration.

6. Effect of improving fuel atomization using air-assist fuel nozzle, can type combustor.

7. NASA premixed primary zone test section.

8. Nitrogen oxides emissions from premix tests using propane fuel.

9. Ultra-low $\mathrm{NO}_{\mathrm{X}}$ combustor concepts.

(a) Jet-induced combustor concept.

(b) Vortex airblast combustor concept.

(c) Catalytic combustor concept.

10. NASA experimental swirl-can-modular combustor.

(a) Photo of full annular combustor.

(b) Cross-sectional view of full annular combustor.

(c) Module components.

11. Comparison of oxides of nitrogen emission levels from conventional combustors and the NASA swirl-can-modular combustor takeoff conditions.

12. Experimental clean combustor program, phase 2.

(a) T2 Class, CF6-50 engine.

(b) T2 Class, JT9D engine.

13. Pollution reduction technology program, phase I configurations.

(a) T4 Class, JT-8D engine.

(b) T1 Class, TFE-731 engine.

(c) P2 Class, 501-D22 engine. 
Figure Captions - Concluded.

14. Emission level reduction status, T2 class engines.

15. High altitude cruise $\mathrm{NO}_{\mathrm{X}}$ reduction status simulated supersonic cruise conditions.

16. Research hydrogen generator for catalytic steam reformation CATALYST

$$
\text { of methanol } \mathrm{CH}_{3}+\mathrm{H}_{2} \mathrm{O}+\mathrm{HEAT} \stackrel{\mathrm{CATAL}}{\longrightarrow} 3 \mathrm{H}_{2}+\mathrm{CO}_{2} \text {. }
$$


Table I. - Gas Turbine Engine Exhaust Constituents

\begin{tabular}{|c|c|c|}
\hline Constituents & Source & $\begin{array}{c}\text { Estimated } \\
\text { concentration }\end{array}$ \\
\hline $\begin{array}{l}\mathrm{N}_{2} \\
\mathrm{O}_{2} \\
\mathrm{~A}\end{array}$ & $\begin{array}{l}\text { Air } \\
\text { Air } \\
\text { Air }\end{array}$ & $\begin{array}{l}77 \%(\mathrm{Vol}) \\
16.6 \%(\mathrm{Vol}) \\
0.9 \%(\mathrm{Vol})\end{array}$ \\
\hline $\begin{array}{l}\mathrm{H}_{2} \mathrm{O} \\
\mathrm{CO}_{2}\end{array}$ & $\begin{array}{l}\text { Eff Combustion } \\
\text { Eff Combustion }\end{array}$ & $\begin{array}{l}2.7 \%(\mathrm{Vol}) \\
2.8 \%(\mathrm{Vol})\end{array}$ \\
\hline $\begin{array}{c}\mathrm{CO} \\
\text { Unburned } \mathrm{HC} \\
\text { Partially oxidized } \mathrm{HC} \\
\mathrm{H}_{2} \\
\text { Smoke (particulates) }\end{array}$ & $\begin{array}{l}\text { INEFF Combustion } \\
\text { INEFF Combustion } \\
\text { INEFF Combustion } \\
\text { INEFF Combustion }\end{array}$ & $\begin{array}{c}10-50 \text { PPM } \\
5-25 \text { PPMC } \\
5-50 \text { PPM } \\
0.4-50 \text { PPM (MASS) }\end{array}$ \\
\hline $\mathrm{NO}, \mathrm{NO}_{2}$ & Heating of air & $50-400 \mathrm{PPM}$ \\
\hline $\begin{array}{c}\mathrm{SO}_{2}, \mathrm{SO}_{3} \\
\text { Trace Metals }\end{array}$ & $\begin{array}{l}\text { Fuel } \\
\text { Fuel }\end{array}$ & $\begin{array}{l}1-10 \text { PPM } \\
5-20 \text { PPB }\end{array}$ \\
\hline
\end{tabular}


Table II. - Environmental Protection Agency Emission

Levels For The LTO Cycle

1979 EPA Standards

\begin{tabular}{|c|c|c|c|c|c|c|c|c|}
\hline \multirow{2}{*}{$\begin{array}{c}\text { Engine } \\
\text { class }\end{array}$} & \multicolumn{2}{|c|}{ THC } & \multicolumn{2}{|c|}{${ }^{*}$ CO } & \multicolumn{2}{c|}{${ }^{*}$ NO $_{\mathrm{x}}$} & \multicolumn{2}{c|}{ Smoke } \\
\cline { 2 - 9 } & Pres & Std & Pres & Std & Pres & Std & Pres & Std \\
\hline T1 & $4-16$ & 1.6 & $15-60$ & 9.4 & $2.5-4.5$ & 3.7 & ---- & $<32$ \\
\hline T1, T3, T4 & $2-21$ & 0.8 & $7-20$ & 4.3 & $3-10$ & 3.0 & $20-65$ & $<25$ \\
\hline P2 & $6-12$ & 4.9 & $20-30$ & 26.8 & $6-10$ & 12.9 & ---- & $<50$ \\
\hline Piston & $2.5-4.5$ & 1.9 & $50-120$ & 42 & $0.2-1.3$ & 1.5 &.--- & --- \\
\hline
\end{tabular}

1981 EPA Standards

\begin{tabular}{|l|l|l|l|l|l|l|l|l|}
$\mathrm{T} 1, \mathrm{~T} 3, \mathrm{~T} 4$ & $2-21$ & 0.4 & $7-20$ & 3.0 & $3-10$ & 3.0 & $20-65$ & $<25$ \\
\hline
\end{tabular}

T1 - Turbojet/fan engines with less than 8000 pounds thrust.

T2 - Turbojet/fan engines with more than 8000 pounds thrust.

T3 - JT3D engines.

T4 - JT8D engines.

P2 - Turboprop engines.

* - Pounds/1000 pounds thrust - hours/cycle or pounds/1000horsepower - hours/cycle. 
Table III. - Assessment Of Pollution Control Techniques

For Gas Turbine Combustors

\begin{tabular}{|c|c|c|}
\hline $\begin{array}{l}\text { Control } \\
\text { technique }\end{array}$ & Application difficulty & Reduction potential \\
\hline $\begin{array}{l}\text { Air-Assist Fuel } \\
\text { Atomization }\end{array}$ & $\begin{array}{l}\text { Minor } \\
\text { Modification } \\
*^{*} \text { (Low development risk) }\end{array}$ & $\begin{array}{l}\text { Good for } \mathrm{CO} \& \mathrm{THC} \\
\text { Negligible for } \mathrm{NO}_{\mathrm{X}}\end{array}$ \\
\hline $\begin{array}{l}\text { Air Blast } \\
\text { Fuel Atomization }\end{array}$ & $\begin{array}{l}\text { Moderate } \\
\text { Modification } \\
\text { (Low development risk) }\end{array}$ & $\begin{array}{l}\text { Good for } \mathrm{CO} \& \mathrm{THC} \\
\text { Small for } \mathrm{NO}_{\mathrm{x}}\end{array}$ \\
\hline Fuel Scheduling & $\begin{array}{l}\text { Moderate } \\
\text { Modification } \\
\text { (Moderate development risk) }\end{array}$ & $\begin{array}{l}\text { Excellent for } \mathrm{CO} \& \mathrm{THC} \\
{ }^{*} \text { No effect for } \mathrm{NO}_{\mathrm{x}}\end{array}$ \\
\hline $\begin{array}{l}\text { Leaner Fuel/ } \\
\text { Mixtures }\end{array}$ & $\begin{array}{l}\text { Moderate } \\
\text { Modification } \\
\text { (Moderate development } \text { risk) }\end{array}$ & $\begin{array}{l}\text { Poor for } \mathrm{CO} \& \mathrm{THC} \\
\text { Moderate for } \mathrm{NO}_{\mathrm{x}}\end{array}$ \\
\hline Modular Combustor & $\begin{array}{l}\text { Major } \\
\text { Modification } \\
\text { (Moderate development risk) }\end{array}$ & $\begin{array}{l}* \text { Poor for } \mathrm{CO} \& \mathrm{THC} \\
\text { Excellent for } \mathrm{NO}_{\mathrm{x}}\end{array}$ \\
\hline Premixing Fuel and Air & $\begin{array}{l}\text { Major } \\
\text { Modification } \\
\text { (High development risk) }\end{array}$ & $\begin{array}{l}\text { Excellent for } \mathrm{CO} \& \mathrm{THC} \\
\text { Excellent for } \mathrm{NO}_{\mathrm{x}}\end{array}$ \\
\hline Catalytic Combustor & $\begin{array}{l}\text { Major } \\
\text { Modification } \\
\text { (Very high development risk) }\end{array}$ & $\begin{array}{l}{ }^{*} \text { Poor for } \mathrm{CO} \& \mathrm{THC} \\
\text { Excellent for } \mathrm{NO}_{\mathrm{x}}\end{array}$ \\
\hline
\end{tabular}

* May be excellent if used in conjunction with other techniques.

* * Development $\mathrm{risk}$ is defined as the ability to convert a demonstrated experimental technique into a workable engine combustor. 
Table IV. - Candidate Emission Reduction Techniques

For Piston Engines

1. Fuel Additives
A. Methanol

2. Emission Control Add-On
A. Thermal Reactor
B. Catalytic Reactor
C. Hydrogen Injection
D. Water-Alcohol Injection

3. Fuel Distribution and Ignition System
A. Ultrasonic Fuel Atomization
B. Thermal Fuel Vaporization
C. High-Energy Multiple-Spark Ignition

4. Engine Geometry Modifications
A. Improved Cooling
B. Run Lean and Supercharge
C. Stratified Charge 


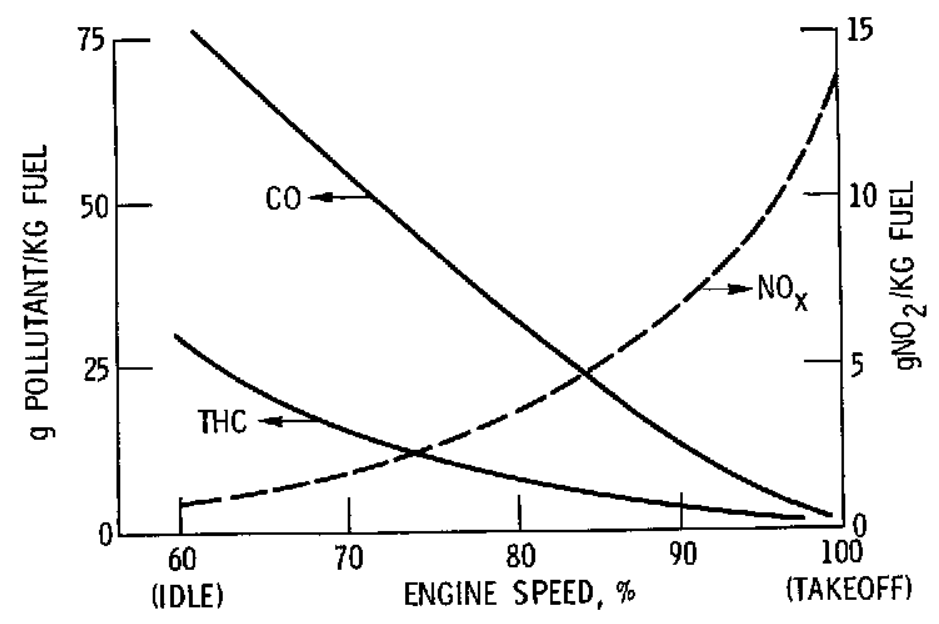

Figure 1. - Typical aircraft gas turbine engine exhaust emission characteristics.

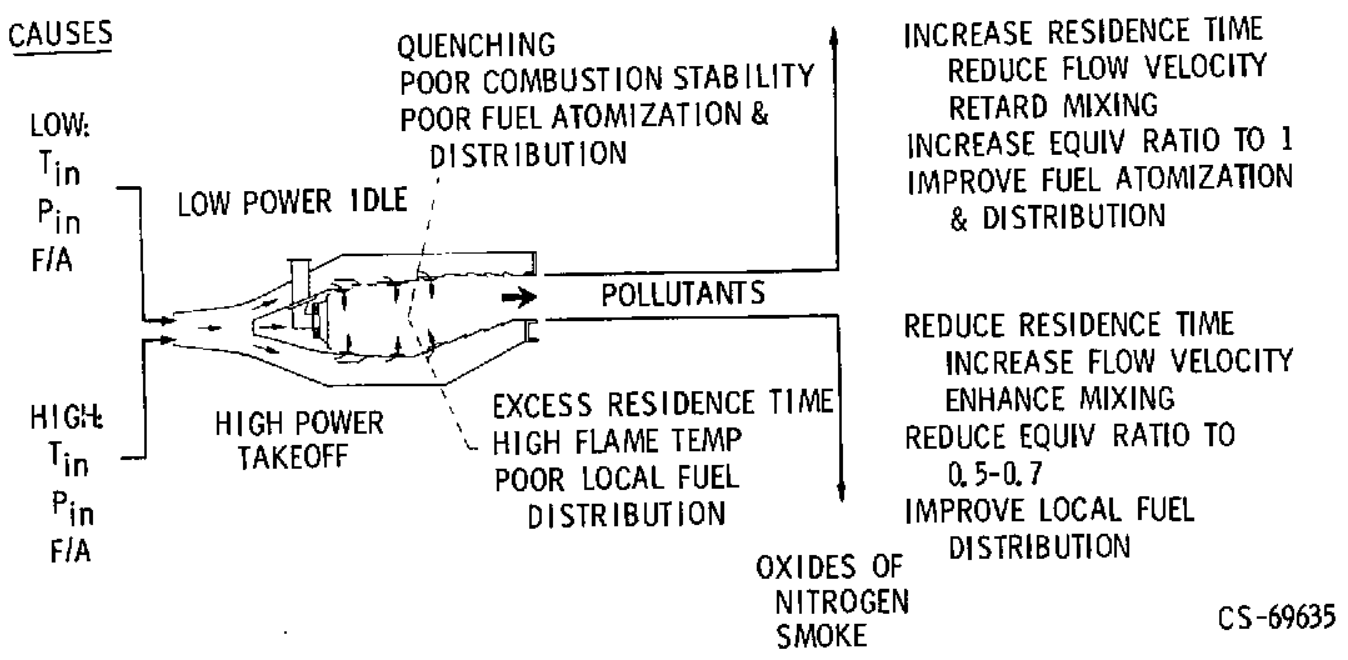

Figure 2. - Aircraft gas turbine combustor pollution considerations. 


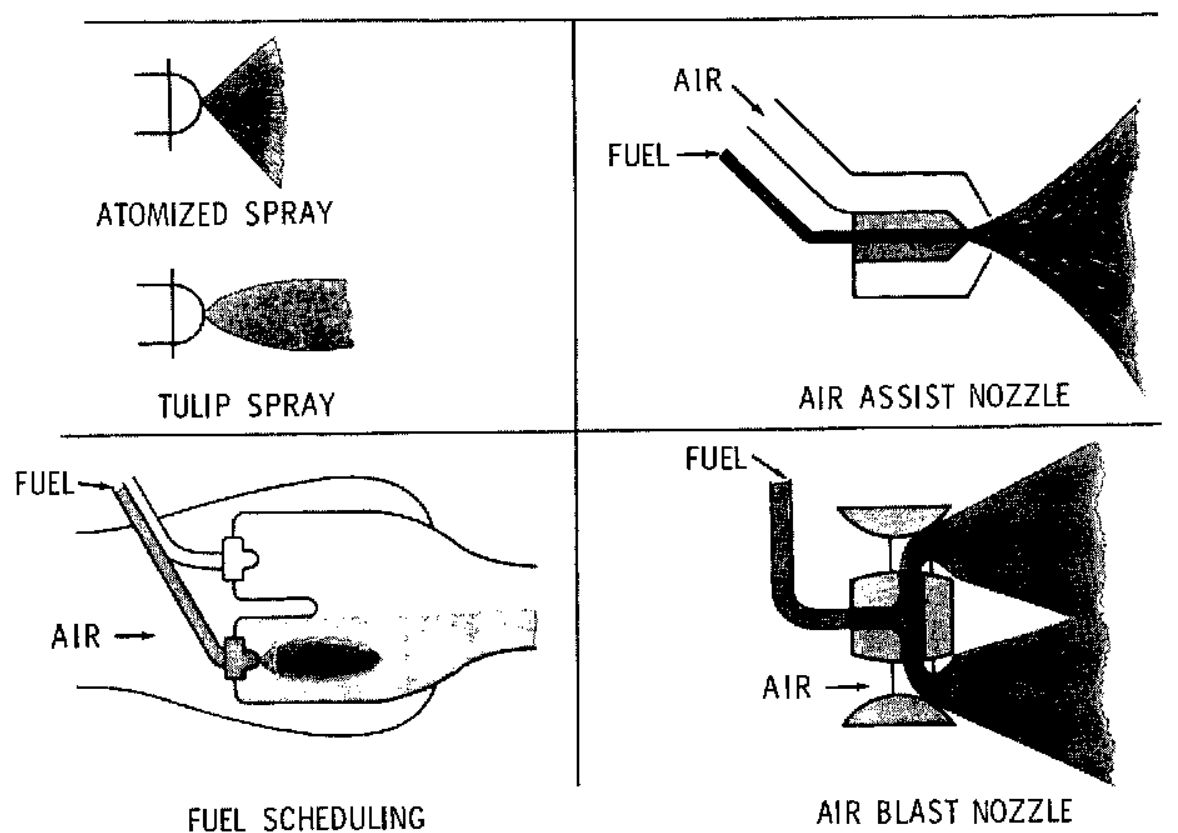

Figure 3. - Emission reduction techniques at idle.

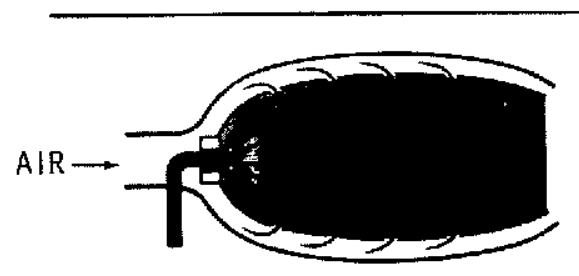

EMISSIONS REDUCED BY:

LOWER FLAME TEMP

REDUCED TIME IN FLAME

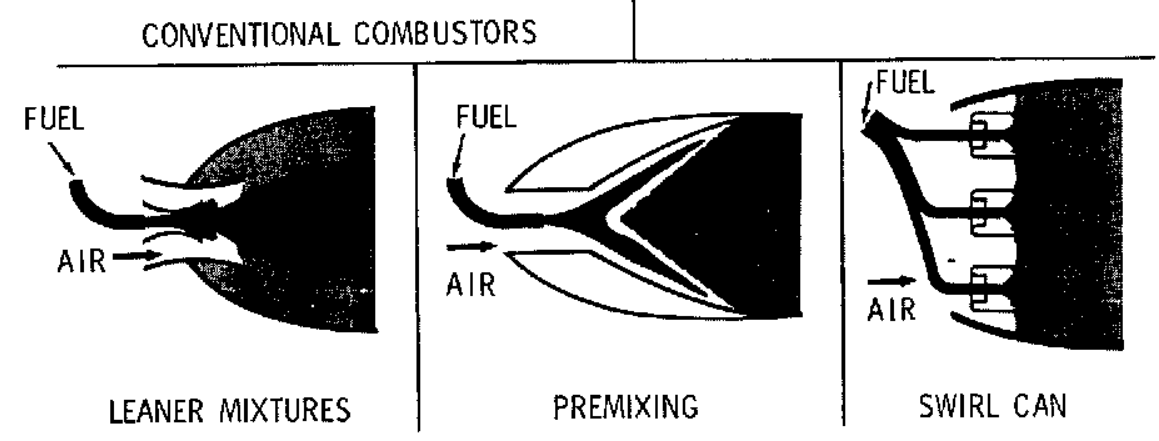

Figure 4. - Emission reduction techniques at full power. 


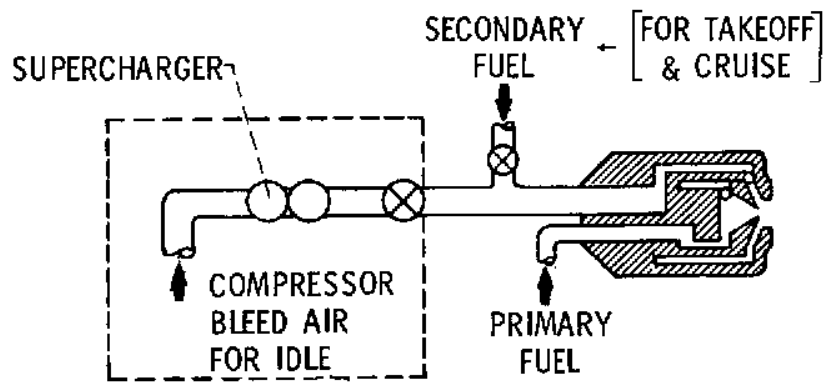

$\mathrm{CS}-60848$

Figure 5. - Schematic of an air-assist fuef injection configuration.

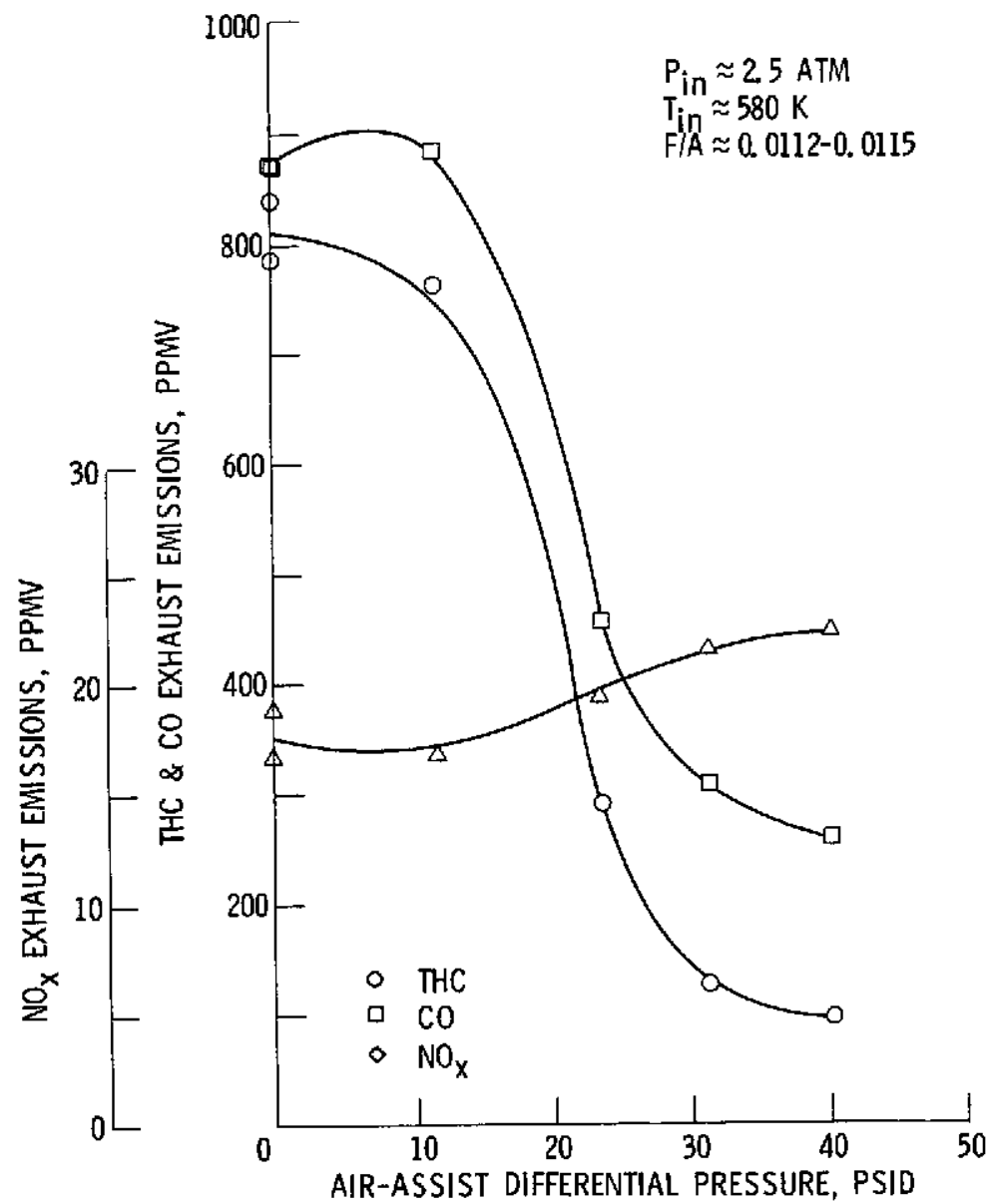

Figure 6. - Effect of improving fuel atomization using air-assist fuel nozzle, can type combustor. 


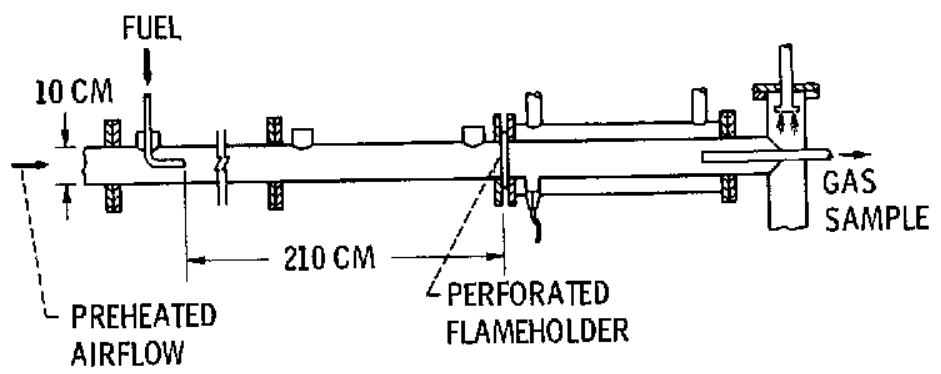

Figure 7. - NASA premixed primary zone test section.

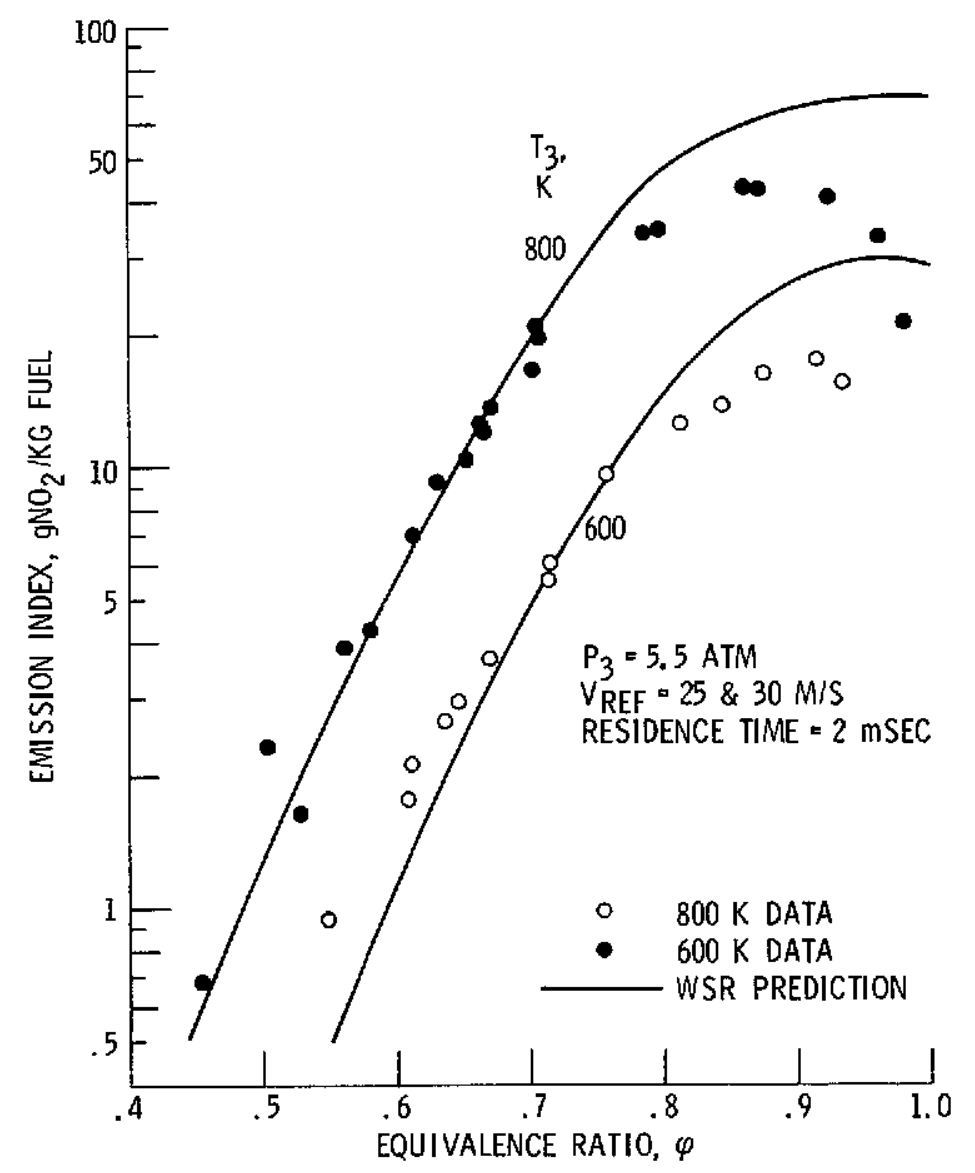

Figure 8. - Nitrogen oxides emissions from premix tests using propane fuel.

\section{DRIGINAL PAGE IS DT POOR QUALITY}




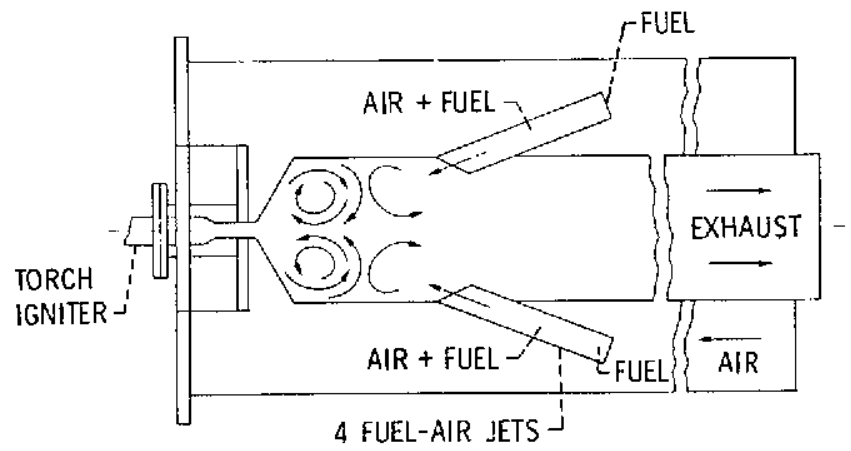

(a) JET-INDUCED COMBUSTOR CONCEPT.

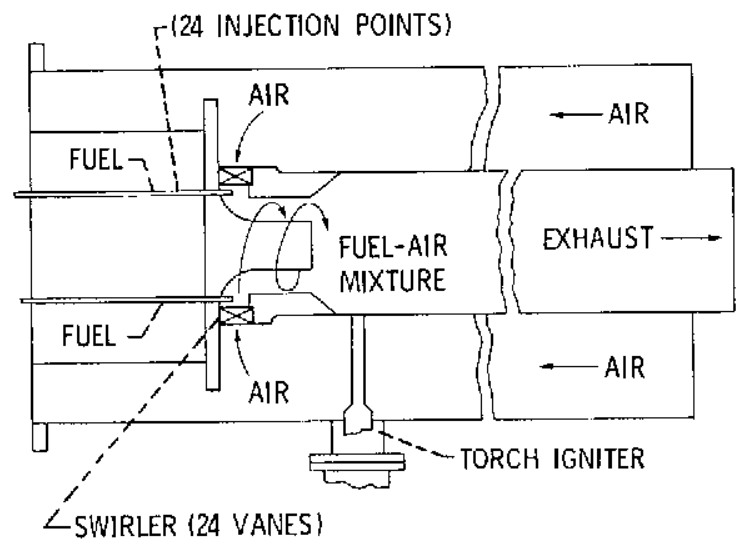

(b) VORTEX AIRBLAST COMBUSTOR CONCEPT.

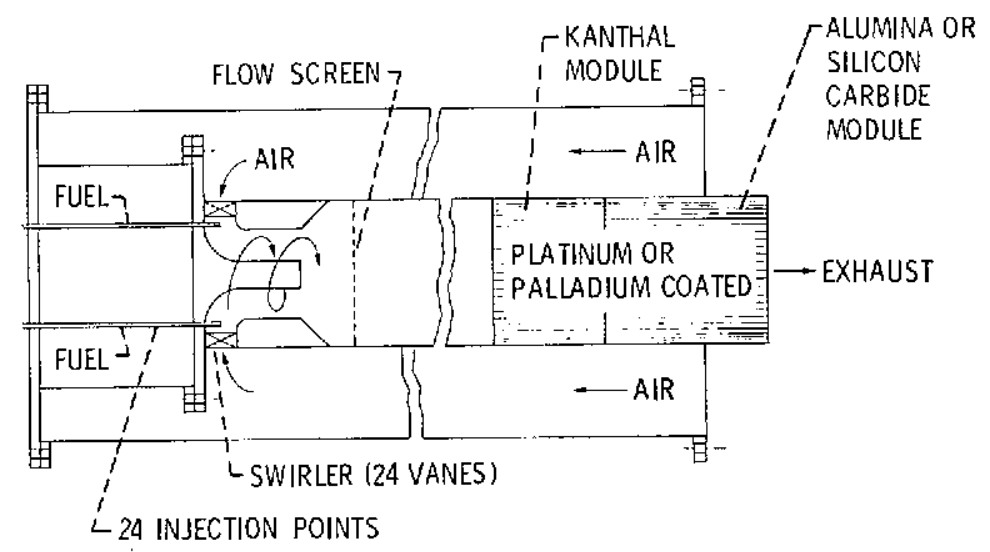

(c) CATALYTIC COMBUSTOR CONCEPT.

Figure 9. - Ultra-low $\mathrm{NO}_{x}$ combustor concepts. 


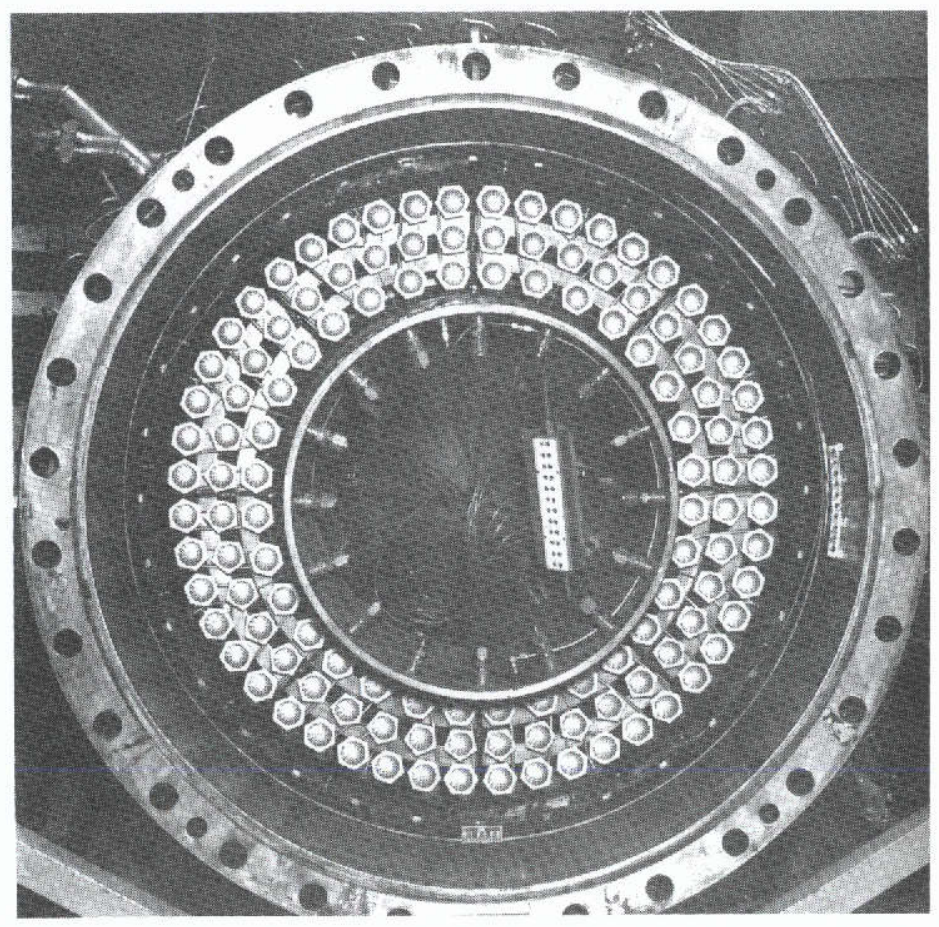

(a) PHOTO OF FULL ANNULAR COMBUSTOR.

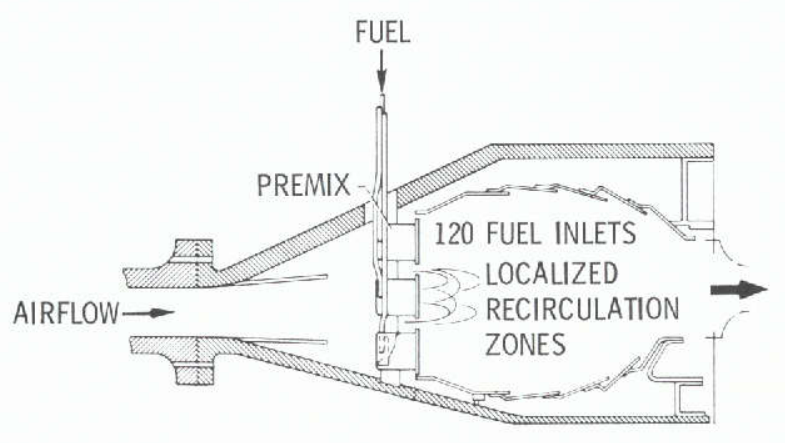

(b) CROSS-SECTIONAL VIEW OF FULL ANNULAR COMBUSTOR.

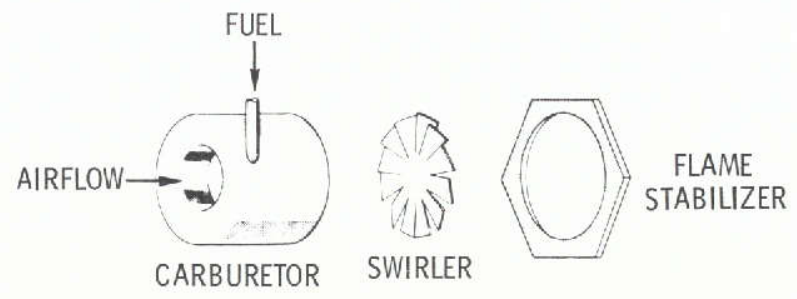

(c) MODULE COMPONENTS.

Figure 10. - NASA Experimental Swirl-Can-Modular Combustor. 


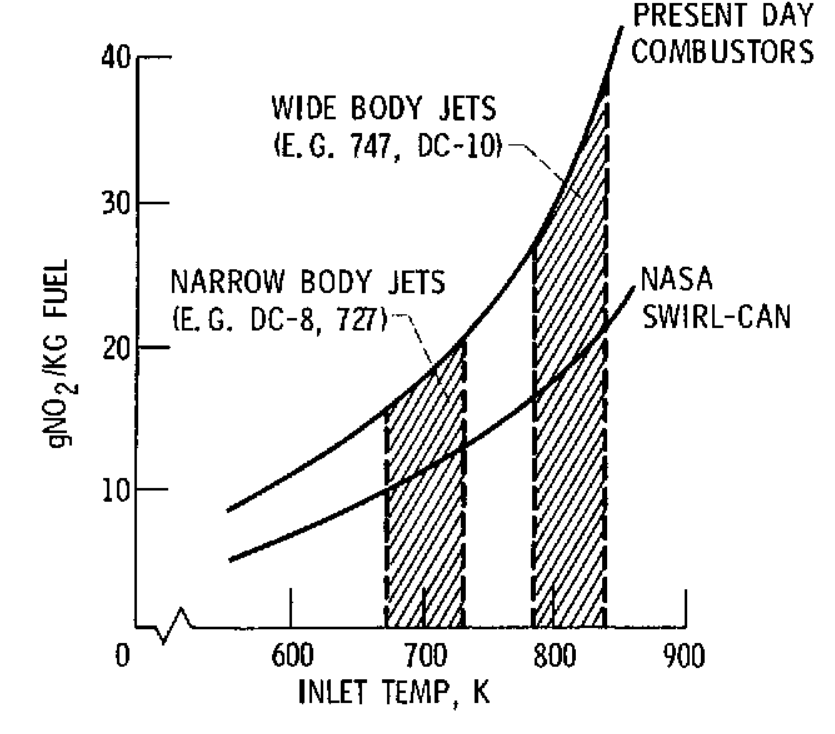

Figure 1l. - Comparison of oxides of nitrogen emission levels from conventional combustors and the NASA swirl-can-modular combustor takeoff conditions.

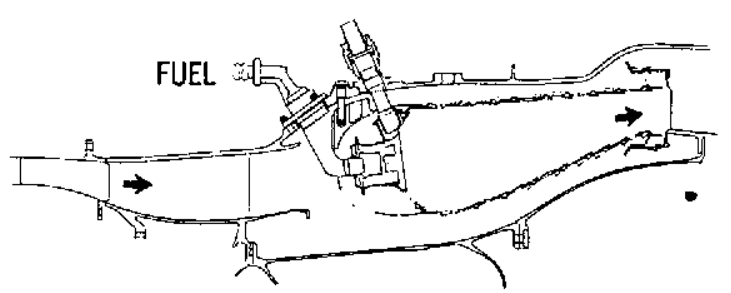

A - CF6-50 ENGINE COMBUSTOR

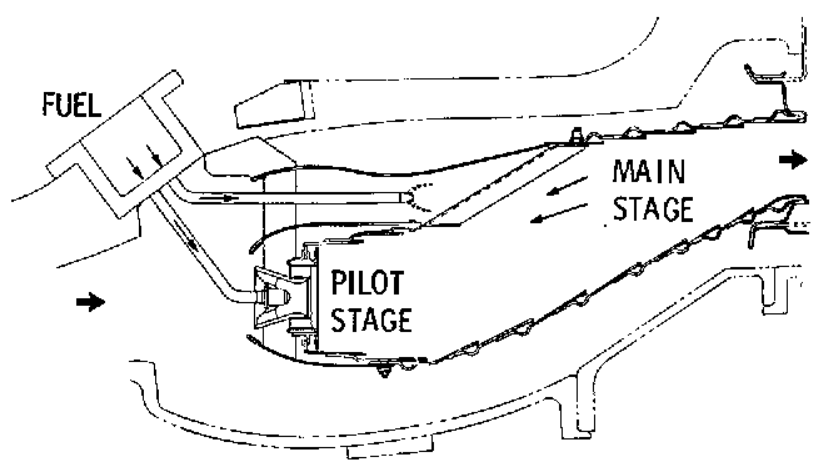

B - RADIAL/AXIAL STAGED COMBUSTOR

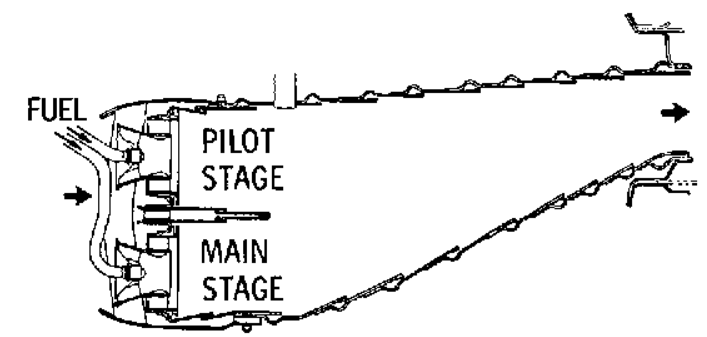

C - DOUBLE ANNULAR COMBUSTOR

(a) T2 CLASS, CF6-50 ENGINE.

Figure 12 - Experimental clean combustor program, phase 2. 


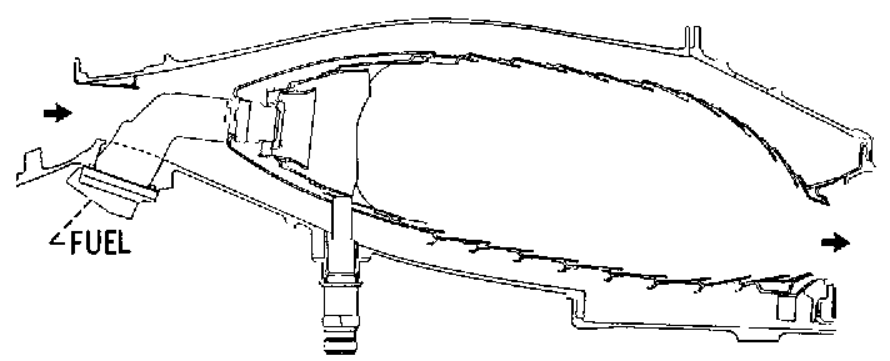

A - JT9D ENGINE COMBUSTOR

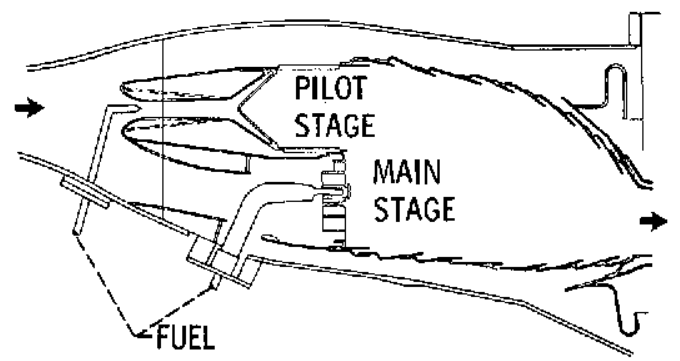

B - HYBRID COMBUSTOR

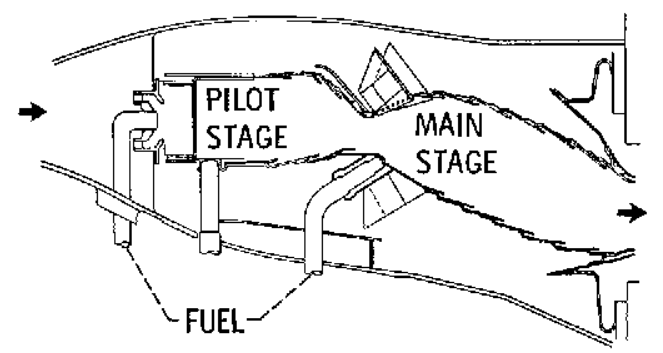

C - VORBIX COMBUSTOR

(b) T2 CLASS, JT9D ENGINE.

Figure 12 - Concluded 


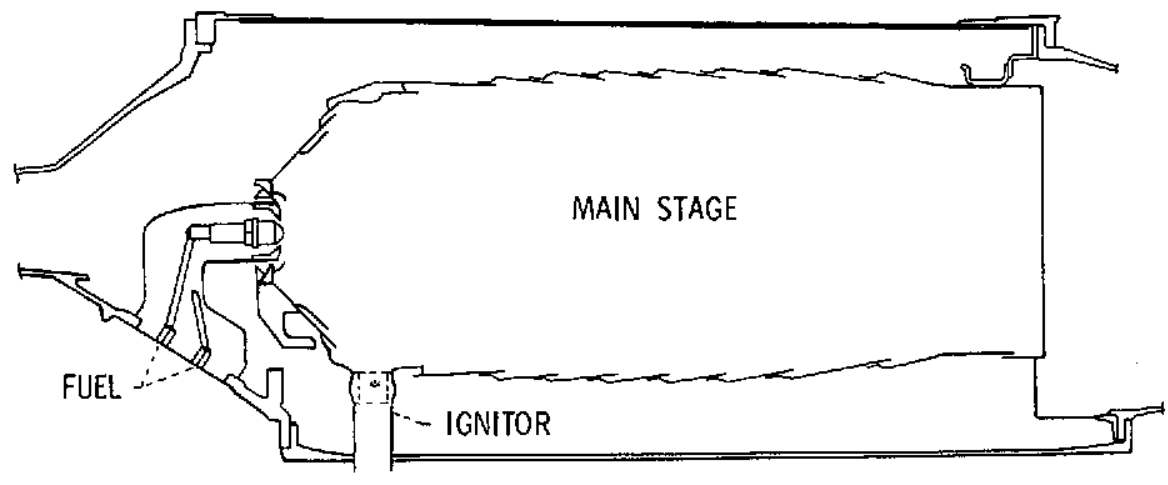

A - CONVENTIONAL COMBUSTOR

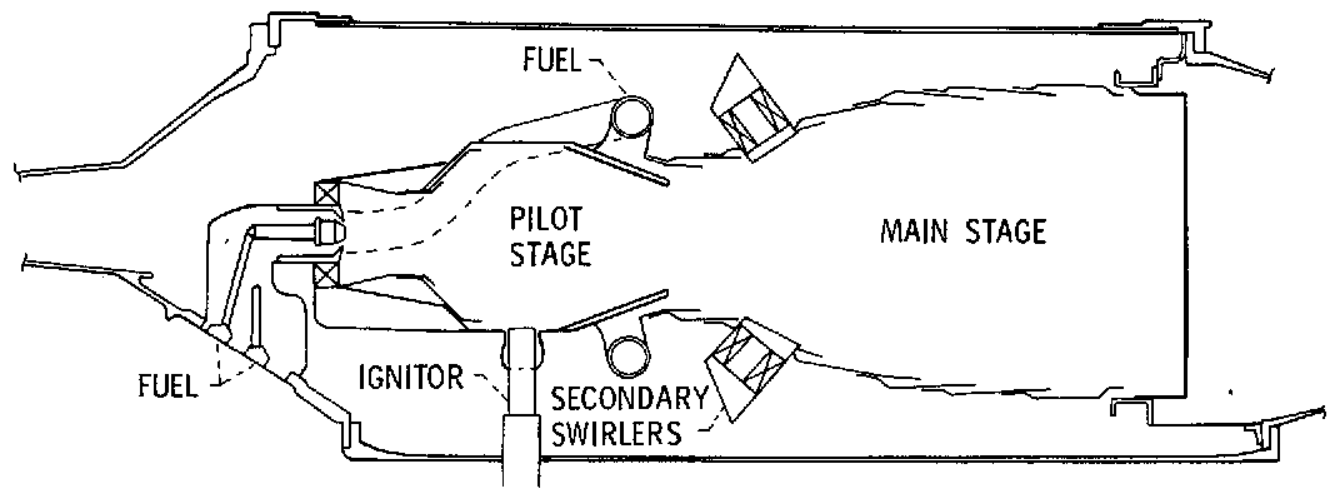

B - SWIRL COMBUSTOR

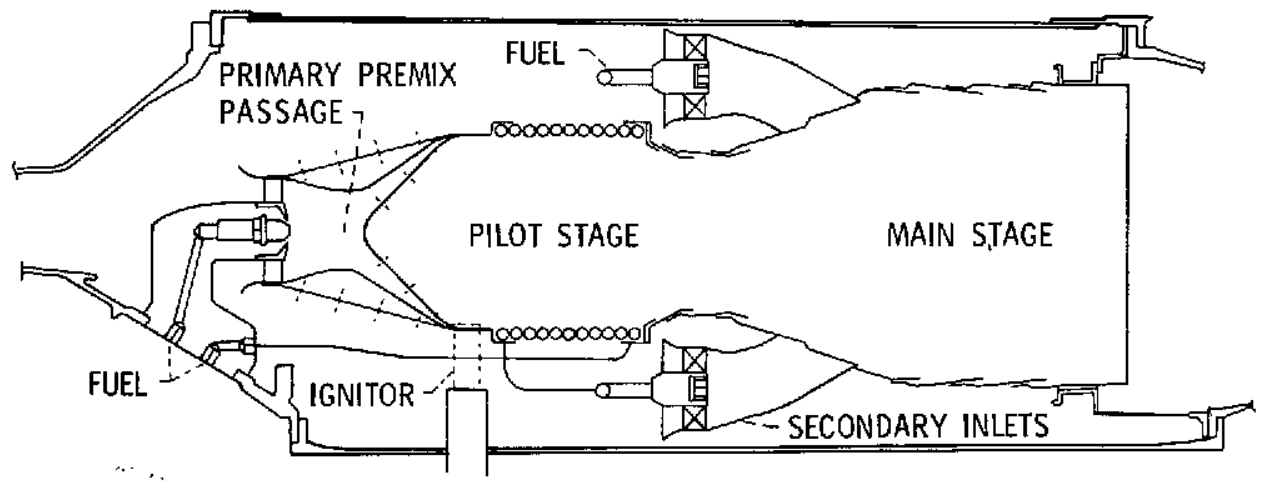

C - STAGED PREMIX COMBUSTOR

(a) T4 CLASS, JT-8D ENGINE.

Figure 13. - Pollution reduction technology program, phase I configurations. 


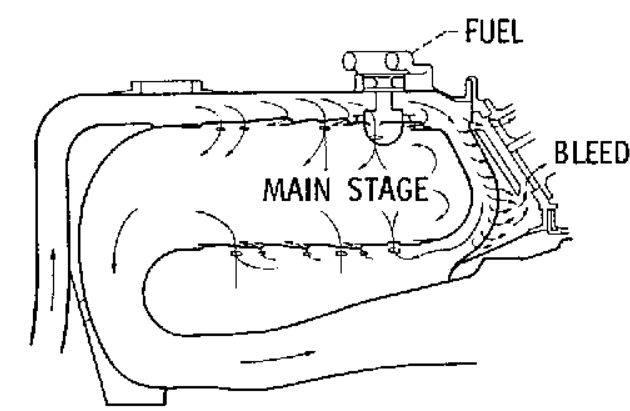

A - MODIFICATIONS TO BASELINE COMBUSTOR

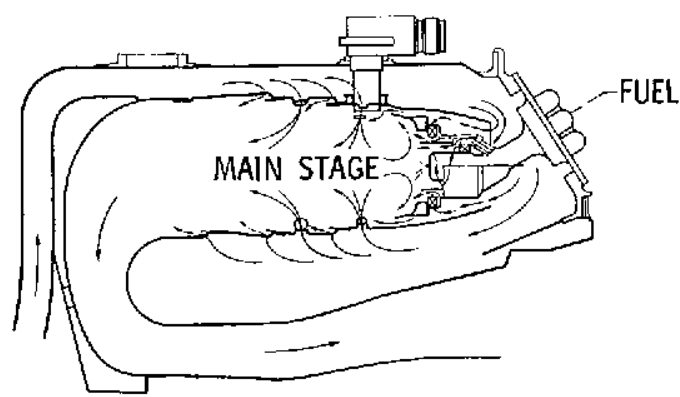

B - PILOTED AIRBLAST AND/OR AIR ASSIST FUEL INJECTION

FUEL

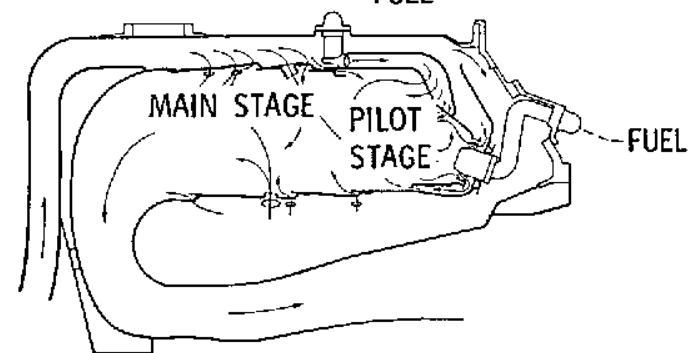

C - PILOTED PREMIXIPREVAPORIZATION FUEL INJECTION

(b) Tl CLASS, TFE-731 ENGINE.

Figure 13. - Continued.

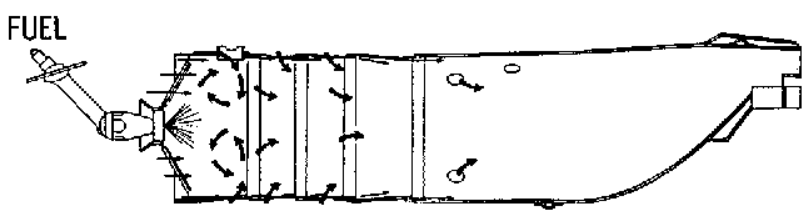

A - MODEL 501-D22A STANDARD COMBUSTOR
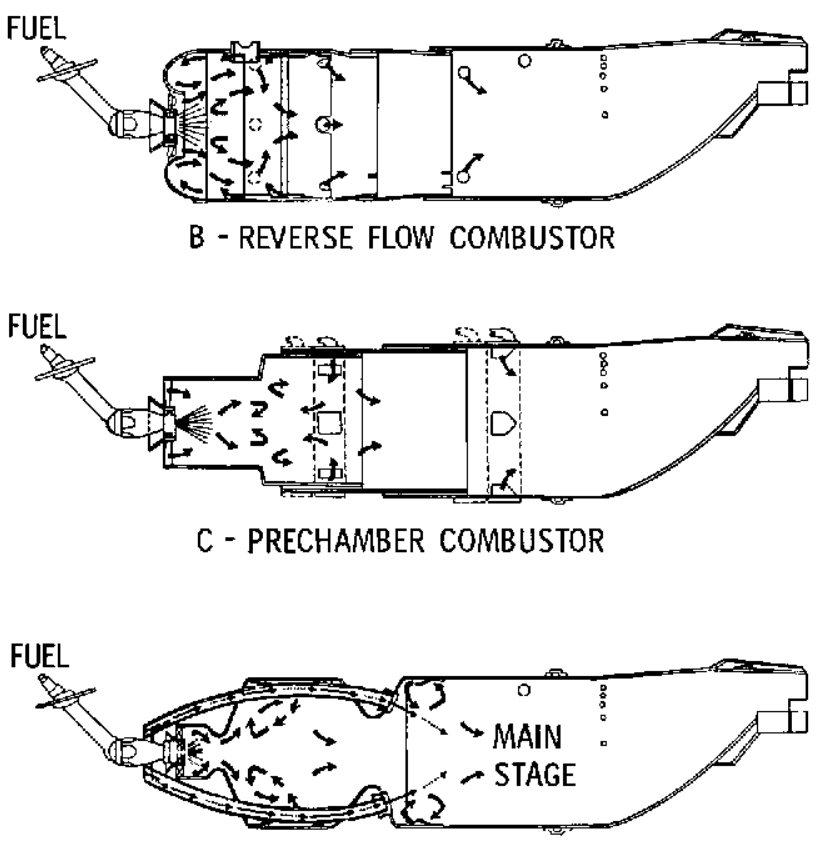

D - STAGED FUEL COMBUSTOR

(c) P2 CLASS, 501-D22 ENGINE.

Figure 13. - Concluded. 


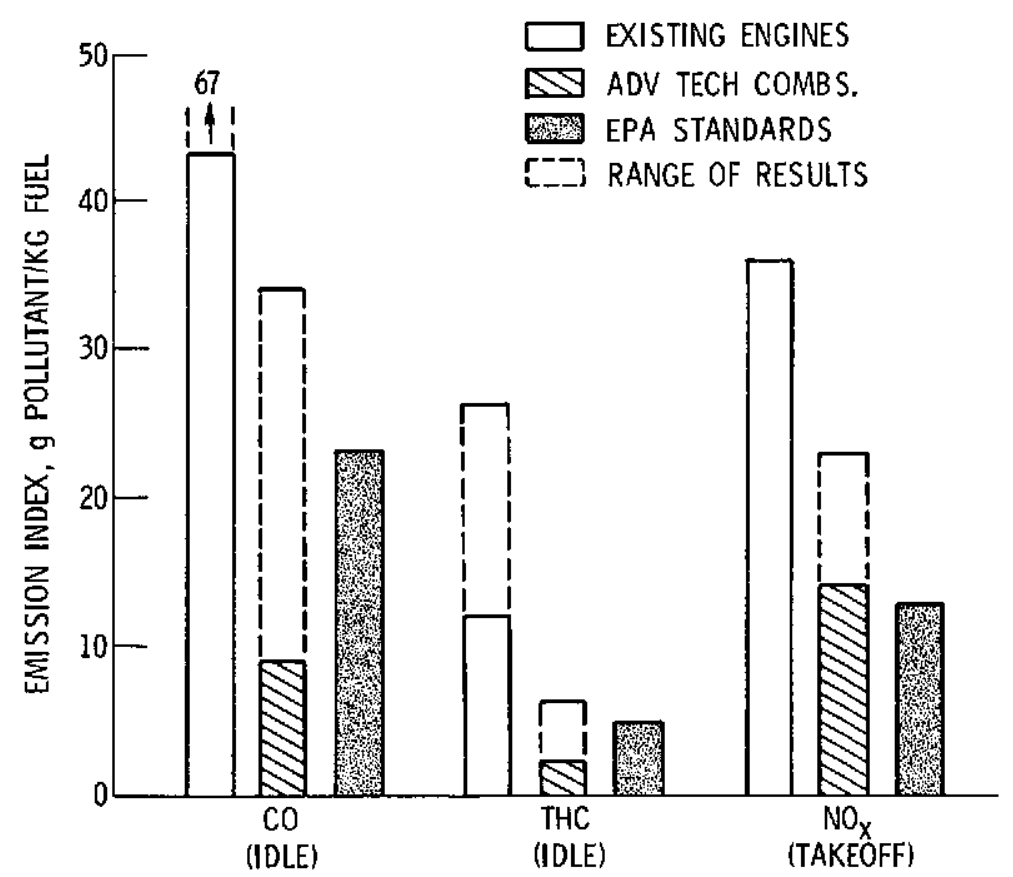

Figure 14. - Emission level reduction status, T2 class engines.

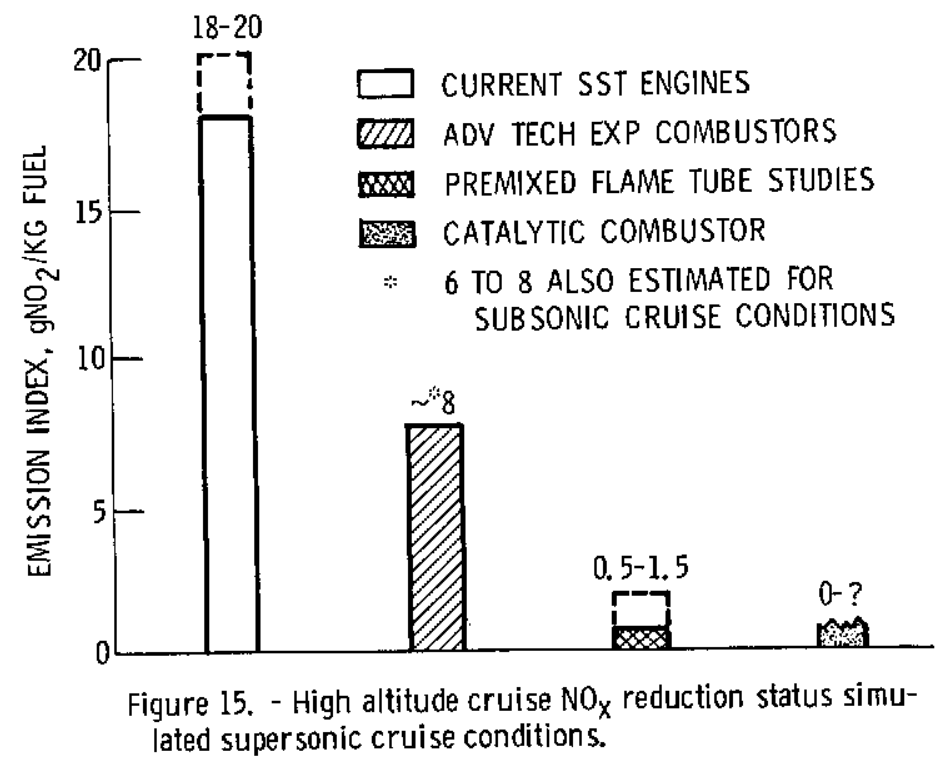




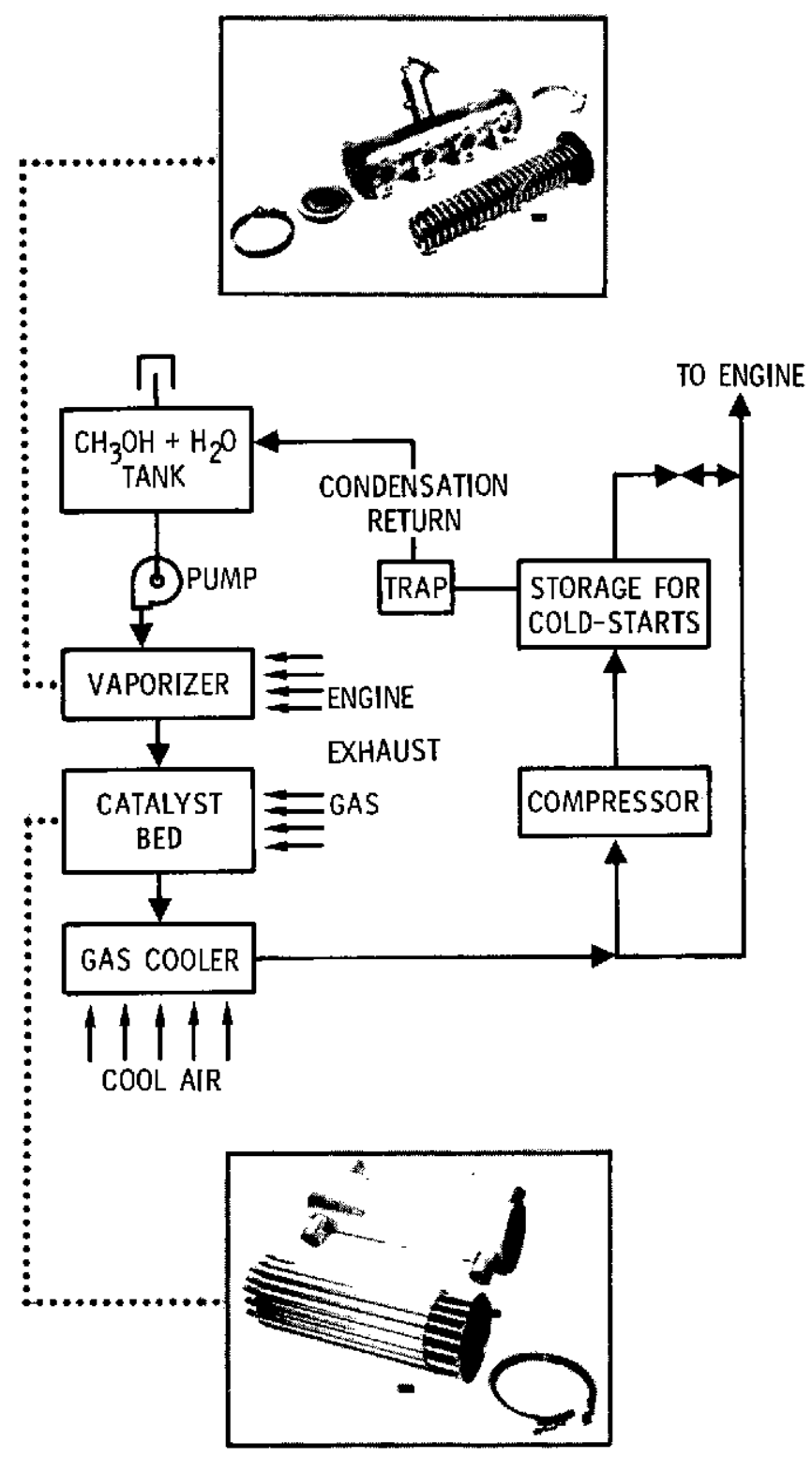

Figure 16. - Research hydrogen generator for catalytic steam reformation of methanol

$$
\mathrm{CH}_{3} \mathrm{OH}+\mathrm{H}_{2} \mathrm{O}+\mathrm{HEAT} \stackrel{\text { CATALYST }}{\longrightarrow} 3 \mathrm{H}_{2}+\mathrm{CO}_{2}
$$

